\title{
PENDUGAAN ELASTISITAS PENAWARAN OUTPUT DAN PERMINTAAN INPUT USAHATANI JAGUNG
}

\author{
Adang Agustian ${ }^{1}$ dan Sri Hartoyo ${ }^{2}$ \\ 1 Pusat Sosial Ekonomi dan Kebijakan Pertanian, Badan Litbang Pertanian, Kementerian Pertanian \\ Jalan Ahmad Yani 70 Bogor 16161, Telepon 0251-8333964, Faks. 0251-8314496 Bogor \\ ${ }^{2}$ Fakultas Ekonomi dan Manajemen Institut Pertanian Bogor \\ Jalan Raya Darmaga Kampus IPB Darmaga Bogor 16680 \\ E -mail: aagustian08@gmail.com
}

Diterima 18 Januari 2012 / Disetujui 27 September 2012

\begin{abstract}
This study aims to determine the effect of changes in output and input prices, corn research expenditures and road infrastructure on output supply and input demand for corn in the Province of East Java and West Java. The data that are analyzed are those of structure of costs of corn farming in the Province of East Java and West Java in 1985-2009. Estimation model employed is the method of Seemingly Unrelated Regression. The results showed that the output supply of corn both in the province of East Java and West Java are elastic to its price changes, however it is inelastic to the price changes of: seed, urea, TSP and labor. Input demand of seed, urea, TSP and labor area inelastic to their price changes. Policy implications of this research is efforts to increase the supply of corn can be carried out by increasing its price, expenditures of corn research, and road infrastructure.
\end{abstract}

Keywords: supply elasticity, demand elasticity, corn farming, cost structure

\begin{abstract}
Abstrak: Penelitian ini bertujuan mengetahui pengaruh perubahan dalam output dan harga input, pengeluaran penelitian jagung dan infrastruktur jalan pada pasokan output dan permintaan input untuk jagung di provinsi Jawa Timur dan Jawa Barat. Data yang dianalisis adalah struktur biaya pertanian jagung di provinsi Jawa Timur dan Jawa Barat pada tahun 1985-2009. Model estimasi yang digunakan adalah metode Seemingly Unrelated Regression. Hasil penelitian menunjukkan bahwa pasokan output jagung baik di provinsi Jawa Timur dan Jawa Barat yang elastis terhadap perubahan harga, namun inelastis terhadap perubahan harga: benih, urea, TSP, dan tenaga kerja. Permintaan input benih, urea, TSP, dan tenaga kerja inelastis terhadap perubahan harga masing-masing input. Implikasi kebijakan dari penelitian ini adalah upaya untuk meningkatkan pasokan jagung dapat dilakukan dengan meningkatkan harga, pengeluaran penelitian jagung, dan infrastruktur jalan.
\end{abstract}

Kata kunci: elastisitas penawaran, elastisitas permintaan, pertanian jagung, struktur biaya

\section{PENDAHULUAN}

Jagung merupakan komoditas tanaman pangan sebagai sumber karbohidrat kedua setelah beras yang sangat berperan dalam menunjang ketahanan pangan. Kebutuhan jagung nasional selama periode 2000-2009 mengalami peningkatan sebesar 3,40 persen per tahun. Pada tahun 2000, total kebutuhan jagung mencapai 10,72 juta ton, kemudian meningkat menjadi 15,12 juta ton pada tahun 2009 (FAO, 2009; dan Zubachtirodin, Pabbage dan Subandi , 2007).

Pada periode 2000-2009, luas panen dan produksi jagung nasional mengalami peningkatan masing-masing sebesar 2,35 dan 7,07 persen per tahun. Pada tahun 2000, produksi jagung nasional mencapai 9,68 juta ton kemudian meningkat menjadi 17,63 juta ton pada tahun 2009. Di provinsi Jawa Timur, peningkatan produksi jagung mencapai 4,22 persen per 
tahun, yaitu dari 3,49 juta ton pada tahun 2000 menjadi 5,27 juta ton pada tahun 2009. Sementara di provinsi Jawa Barat, peningkatan produksi jagung sebesar 7,08 persen per tahun, yaitu dari 412,02 ribu ton tahun 2000 menjadi 784.61 ribu ton pada tahun 2009 (BPS, 2010).

Produktivitas jagung nasional tahun 2009 mencapai 4,24 ton/ha, yang relatif lebih kecil dibandingkan dengan produktivitas jagung seperti di Amerika Serikat yang mencapai 10.34 ton/ha dan China mencapai 5,35 ton/ha. Rendahnya produksi jagung nasional, sementara kebutuhannya meningkat pesat menyebabkan terjadinya ketimpangan pemenuhan kebutuhan. Untuk mencukupi berbagai kebutuhan, dilakukan impor jagung yang mencapai 1,29 juta ton tahun 2000 dan turun menjadi 300 ribu ton tahun 2009 . Sementara rendahnya produktivitas jagung nasional pada beberapa sentra produksi jagung seperti di provinsi Jawa Timur dan Jawa Barat antara lain disebabkan masih banyaknya petani yang menanam varietas lokal dan varietas unggul lama yang benihnya telah mengalami degradasi secara genetik dan belum dimurnikan. Sampai tahun 2010, penggunaan benih jagung hibrida baru sekitar 50 persen dari total pemakaian benih jagung di Indonesia (Bisnis Indonesia, 2010). Menurut Kasryno, et.al (2007) bahwa potensi produktivitas jagung hibrida dapat berkisar antara 5-7 ton/ha.

Dalam rangka peningkatan produksi jagung, pemerintah pusat melakukan berbagai kebijakan yang meliputi kebijakan input dan output (Ditjen Tanaman Pangan, 2010). Kebijakan terkait input usahatani jagung antara lain: subsidi pupuk dan bantuan benih. Kebijakan terkait output adalah mendorong pemerintah daerah agar menampung produksi jagung petani pada saat panen, sehingga harganya stabil dan tidak jatuh disaat musim panen. Hal ini karena sejak tahun 1990 kebijakan pengaturan harga dasar jagung sudah tidak ada, dan harga jagung ditentukan oleh mekanisme pasar. Permasalahannya adalah bagaimana pengaruh harga input dan harga output (jagung) terhadap penawaran jagung?.

Dukungan pemerintah dalam hal input adalah berupa subsidi pupuk. Jenis pupuk yang disubsidi tahun 2009 adalah pupuk: urea, SP36,
ZA, NPK Phonska, NPK Pelangi, NPK Kujang dan pupuk organik. Dengan semakin terbatasnya anggaran pemerintah, subsidi pupuk per jenis pupuk semakin kecil sehingga Harga Eceran Tertinggi (HET) pupuk bersubsidi mengalami peningkatan (Nuryartono, 2009). Sementara untuk mendukung penggunaan benih unggul, pada tahun tahun 2009 pemerintah memberikan benih jagung unggul subsidi sebanyak 4 . 266 ton untuk area tanam 225.534 hektar. Selain itu, dukungan peningkatan produksi jagung dilakukan dengan peningkatan produktivitas, perluasan areal tanam, pemberdayaan kelembagaan pertanian dan dukungan infrastruktur pasar, infrastruktur jalan dan pembiayaan (Ekonomi dan Bisnis, 2009). Peningkatan infrastruktur jalan diperlukan untuk memperlancar arus barang dan jasa terutama input yang diperlukan dan pemasaran hasil pertanian pada suatu wilayah. Kegiatan riset pengembangan jagung juga terus dilakukan pemerintah. Pada tahun 2000 pengeluaran riset jagung sebesar Rp 0,19 milyar dan meningkat menjadi Rp13,8 milyar pada tahun 2009. Permasalahannya adalah bagaimana pengaruh infrastruktur pengeluaran riset jagung dan jalan terhadap penawaran jagung?

Untuk menjawab permasalahan-permasalahan di atas maka dilakukan penelitian ini. Secara khusus penelitian ini bertujuan untuk mengetahui elastisitas permintaan input (input variabel dan faktor tetap) dan penawaran output usahatani jagung

Fungsi Produksi dan Keuntungan. Fungsi produksi merupakan fungsi yang menggambarkan hubungan teknis antara input dan output (Debertin, 1986). Dalam proses produksi pertanian terdapat tiga kategori input, yaitu: input variabel, input tetap dan input acak seperti curah hujan. Selanjutnya Fan (1991), Hartoyo (1994) dan Khatri dan Thirtle (1996) mengungkapkan bahwa produksi pertanian dipengaruhi oleh perkembangan teknologi, infrastruktur (jaringan irigasi dan jalan), kelembagaan, dan riset di bidang pertanian.

Apabila $Y$ adalah produksi suatu komoditi, $\mathrm{Xj}$ adalah jumlah input variabel $\mathrm{j}$, dan $\mathrm{Zk}$ adalah input tetap $k$, maka fungsi produksi pada keadaan teknologi tertentu dapat dirumuskan 
sebagai berikut: $Y=f(X j ; Z k)$.

Jika diasumsikan dalam aktivitas usahatani bertujuan memaksimumkan keuntungan, maka dalam jangka pendek keuntungan merupakan selisih antara penerimaan total dikurangi dengan biaya variabel total. Pada tingkat harga output tertentu $(\mathrm{P})$, harga input tertentu $(\mathrm{R})$, dan faktor input tetap $(Z)$ dimana dalam penelitian ini adalah infrastruktur (pengeluaran riset dan jalan), petani memaksimumkan keuntungan yaitu sebagai berikut:

$$
\Pi=P . Y-\sum_{\mathrm{h}=1}^{\mathrm{n}} \mathrm{Rh} \mathrm{Xh}-\lambda \mathrm{F}(\mathrm{X} ; \mathrm{Z})
$$

Keuntungan maksimal dicapai apabila terpenuhi dua syarat, yaitu: first order condition (syarat perlu) dan second order condition (syarat cukup). Untuk syarat kecukupan terpenuhi jika Hessian Determinant lebih besar dari nol. Jika syarat cukup terpenuhi, maka diperoleh $\mathrm{Y}$ dan $X$ optimal, sehingga menghasilkan keuntungan maksimal. Nilai output dan input yang optimum merupakan fungsi dari: $\mathrm{Y}=\mathrm{Y}^{*}(\mathrm{P}, \mathrm{R} ; \mathrm{Z})$ dan $X=X^{*}(P, R, ; Z)$. Dengan mensubstitusikan $Y$ dan $X$ optimal pada persamaan fungsi keuntungan maka akan diperoleh fungsi keuntungan sebagai berikut:

$$
\Pi=\Pi^{*}(\mathrm{P}, \mathrm{R} ; \mathrm{Z})
$$

Fungsi penawaran output dan permintaan input pada penelitian ini diturunkan langsung dari fungsi keuntungan. Dengan menggunakan prinsip Hotteling Lemma, turunan parsial keuntungan maksimal terhadap output merupakan fungsi penawaran output dan turunan parsial keuntungan maksimal terhadap perubahan harga input merupakan fungsi permintaan input.

$$
\begin{aligned}
& \frac{\partial \pi}{\partial P}=\frac{\partial \pi^{*}(P, R ; Z)}{\partial P}=Y i^{*}(P, R ; Z) \\
& \left.\frac{\partial \pi}{\partial R h}=\frac{\partial \pi^{*}(P, R ; Z)}{\partial R h}=-X h^{*}(P, R ; Z)\right)
\end{aligned}
$$

Menurut Lau dan Yotopoulus (1972) bahwa terdapat beberapa keunggulan menggunakan pendekatan dual (fungsi keuntungan), yaitu: (1) fungsi penawaran output dan permintaan input dapat diturunkan secara langsung dengan mudah, (2) penurunan fungsi penawaran output dan permintaan input dari fungsi keuntungan memberikan hasil yang sama jika fungsi tersebut diturunkan dari fungsi produksi, dan (3) analisis menggunakan fungsi keuntungan dapat menghindari masalah bias pada persamaan simultan. Hal ini disebabkan karena pada fungsi keuntungan semua peubah eksogen terletak di sebelah kanan dan peubah endogen terletak di sebelah kiri persamaan.

Pengaruh Harga Output, Harga Input, Teknologi (Riset) dan Infrastruktur Terhadap Produksi. Kebijakan harga merupakan salah satu kebijakan yang dapat menjamin stabilitas harga input dan output serta mencegah agar pendapatan produsen tidak berfluktuatif antar musimnya (Mubyarto, 1989). Produsen yang menghasilkan komoditas jagung, apabila menghadapi kenaikan harga jagung, ceteris paribus, maka jumlah jagung yang ditawarkan (diproduksi) akan meningkat. Sesuai teori ekonomi, jika terjadi perubahan harga komoditas sendiri (jagung), maka produksi hanya bergerak di sepanjang kurva penawaran. Sementara jika terjadi perubahan harga komoditas lainnya (substitusi atau komplemen) atau terjadi perubahan biaya faktor produksi dapat menyebabkan kurva penawaran bergeser baik ke kiri maupun ke kanan.

Kebijakan yang dapat menyebabkan perubahan harga input seperti kebijakan pengurangan subsidi pupuk dan subsidi benih. Menurunnya subsidi pupuk terhadap suatu jenis pupuk tertentu yang menyebabkan HET (Harga Eceran Tertinggi) pupuk meningkat misalnya pupuk urea dan SP36, pada hakekatnya adalah sama dengan kenaikan harga pupuk urea dan SP36. Pada tahun 2005, HET pupuk urea dan SP36 masing-masing sebesar Rp1.050/ $\mathrm{kg}$ dan Rp1.400/kg, kemudian pada tahun 2009 mengalami peningkatan menjadi Rp $1.200 / \mathrm{kg}$ dan Rp1.550/kg. Bahkan di daerah-daerah yang jaraknya jauh dan biaya transportasi mahal, harga eceran pupuk selalu di atas HET. Peningkatan harga pupuk akan menyebabkan berkurangnya jumlah pupuk yang digunakan. Penurunan penggunaan jumlah pupuk yang digunakan produsen (petani) akan menyebab- 
kan menurunnya output yang dihasilkan produsen. Hal ini juga berlaku bagi penggunaan input lainnya (Pindyck and Rubinfeld, 2005).

Sementara itu, menurut Lipsey, et.al. (1984) bahwa terdapatnya inovasi atau teknologi baru hasil penelitian akan menurunkan biaya, sehingga keuntungan akan naik. Selain itu, adanya perubahan teknologi diduga akan berpengaruh terhadap alokasi relatif penggunaan faktor produksi. Hasil penelitian Hartoyo (1994) bahwa peningkatan infrastruktur (riset dan jalan) dapat menyebabkan hasil per hektar jagung meningkat. Menurut Morlok (1995) bahwa perbaikan infrastruktur transportasi termasuk jalan akaan memperlancar bagi suatu daerah untuk menerima sesuai kebutuhan dan memasarkan barang/jasa.

\section{METODE PENELITIAN}

\section{Jenis dan Sumber Data}

Jenis data yang digunakan pada penelitian ini adalah data time series. Data time series yang dikumpulkan adalah data struktur ongkos usahatani jagung di provinsi Jawa Timur dan Jawa Barat. Data struktur ongkos usahatani jagung bersumber: BPS, Pusat Data dan Informasi Pertanian (Pusdatin)-Kementerian Pertanian, dan Dinas Pertanian Tanaman Pangan provinsi Jawa Barat dan Jawa Timur. Pada data struktur ongkos usahatani jagung diperoleh data struktur penerimaan, biaya dan keuntungan usahatani. Dari data tersebut akan dapat diketahui data-data harga output (jagung), harga input (faktor produksi) seperti: benih, pupuk urea, pupuk TSP, dan upah tenaga tenaga kerja. Data lainnya yang digunakan untuk infrastruktur adalah berupa: pengeluaran riset untuk jagung (1985-2009) diperoleh dari Badan Litbang Pertanian-Kementerian Pertanian, dan data infrastruktur jalan dari BPS.

\section{Metode Analisis}

Ada penelitian ini, model fungsi keuntungan yang digunakan adalah fungsi keuntungan translog seperti digunakan Shidu dan Baanante (1981) dan Adeleke, Mattanmi dan Ogunniyi (2008). Fungsi keuntungan translog yang dinormalisasi harga output sebagai berikut:

$$
\begin{aligned}
& \ln \pi^{*}=\alpha_{0}+\sum_{i=1}^{4} \alpha i \ln R i^{*}+ \\
& 0.5 \sum_{i=1}^{4} \sum_{h=1}^{4} \gamma i h \ln R i^{*} \ln R h^{*}+ \\
& \sum_{i=1}^{4} \sum_{k=1}^{4} \gamma i h \ln R i^{*} \ln Z k+\sum_{k=1}^{4} \beta k \ln Z k+ \\
& \sum_{k=1}^{4} \beta k \ln Z k+0.5 \sum_{k=1}^{4} \sum_{j=1}^{4} \phi k j \ln Z k \ln Z j+\lambda D
\end{aligned}
$$

dimana: $\Pi^{*}$ adalah keuntungan yang direstriksi, dinormalkan dengan harga jagung. Satuan keuntungan usahatani adalah $\mathrm{Rp} / \mathrm{ha} ; \mathrm{R}_{\mathrm{i}}{ }^{*}=$ harga input variabel ke $\mathrm{i}$; $\mathrm{i}=1,2,3,4$ berturut-turut harga benih $\left(R_{S}\right)$, harga pupuk urea $\left(R_{U R}\right)$, harga pupuk TSP $\left(\mathrm{R}_{\mathrm{T}}\right)$, dan upah tenaga kerja manusia $\left(R_{W}\right)$. Adapun satuan kempat harga input variabel tersebut, harga benih: $\mathrm{Rp} / \mathrm{kg}$; harga pupuk: $\mathrm{Rp} / \mathrm{kg}$; dan upah tenaga kerja: $\mathrm{Rp} / \mathrm{HK}$; $Z \mathrm{k}=$ input tetap ke $\mathrm{k} ; \mathrm{k}=1,2,3,4$ berturut-turut: biaya lain $\left(Z_{1}\right)$, luas panen jagung $\left(Z_{2}\right)$, pengeluaran riset jagung (Z3), dan infrastruktur jalan (Z4). Adapun satuan untuk biaya lain: Rp/ha; luas panen: hektar; pengeluaran riset jagung: Rupiah; dan infrastruktur jalan: kilometer; D adalah dummy variabel untuk provinsi (1=Jatim, $0=$ Jabar $) ; \mathrm{a}_{0}$ adalah konstanta ; dan $\mathrm{a}_{0} \mathrm{a}_{0} \gamma_{\text {ih }}$ $\delta_{\mathrm{ik}} \beta_{\mathrm{k}} \Phi_{\mathrm{kj}} \lambda_{\mathrm{I}}$ adalah parameter fungsi keuntungan yang diduga.

Berdasarkan persamaan (1) maka dapat diturunkan menjadi persamaan pangsa biaya sebagai berikut:

$$
\begin{aligned}
-\mathrm{R}_{\mathrm{S}}{ }^{*} \mathrm{X}_{\mathrm{S}} & \\
\pi^{*} & \alpha_{\mathrm{S}}+\gamma_{\mathrm{SS}} \ln \mathrm{R}_{\mathrm{S}}{ }^{*}+\gamma_{\mathrm{SUR}} \ln \mathrm{R}_{\mathrm{UR}}{ }^{*}+ \\
& \gamma_{\mathrm{SW}} \ln \mathrm{R}_{\mathrm{W}}{ }^{*}+\gamma_{\mathrm{ST}} \ln \mathrm{R}_{\mathrm{T}}{ }^{*}+\gamma_{\mathrm{S} 1} \ln \mathrm{Z}_{1}+ \\
& \gamma_{\mathrm{S} 2} \ln \mathrm{Z}_{2}+\gamma_{\mathrm{S} 3} \mathrm{Wn} \mathrm{Z}_{3}+\gamma_{\mathrm{S} 4} \ln \mathrm{Z}_{4}+\mathrm{D}
\end{aligned}
$$




$$
\begin{gathered}
-\mathrm{R}_{\mathrm{UR}}{ }^{*} \mathrm{X}_{\mathrm{UR}} \\
\hdashline \alpha^{*} \alpha_{\mathrm{UR}}+\gamma_{\mathrm{URUR}} \ln \mathrm{R}_{\mathrm{UR}}{ }^{*}+\gamma_{\mathrm{URS}} \ln \mathrm{R}_{\mathrm{S}}{ }^{*}+ \\
\gamma_{\mathrm{URW}} \ln \mathrm{R}_{\mathrm{W}}{ }^{*}+\gamma_{\mathrm{URT}} \ln \mathrm{R}_{\mathrm{T}}{ }^{*}+\gamma_{\mathrm{UR} 1} \ln \mathrm{Z}_{1}+ \\
\gamma_{\mathrm{UR} 2} \ln \mathrm{Z}_{2}+\gamma_{\mathrm{UR} 3} \ln \mathrm{Z}_{3}+\gamma_{\mathrm{UR} 4} \ln \mathrm{Z}_{4}+\mathrm{D}
\end{gathered}
$$

$$
\begin{array}{ll}
\frac{-\mathrm{R}_{\mathrm{T}}{ }^{*} \mathrm{X}_{\mathrm{T}}}{\pi^{*}} & \alpha_{\mathrm{T}}+\gamma_{\mathrm{TT}} \ln \mathrm{R}_{\mathrm{T}}{ }^{*}+\gamma_{\mathrm{TS}} \ln \mathrm{R}_{\mathrm{S}}{ }^{*}+ \\
& \gamma_{\mathrm{TW}} \ln \mathrm{R}_{\mathrm{W}}{ }^{*}+\gamma_{\mathrm{TT}} \ln \mathrm{R}_{\mathrm{UR}}{ }^{*}+\gamma_{\mathrm{T} 1} \ln \mathrm{Z}_{1}+ \\
& \gamma_{\mathrm{T} 2} \ln \mathrm{Z}_{2}+\gamma_{\mathrm{T} 3} \ln \mathrm{Z}_{3}+\gamma_{\mathrm{T} 4} \ln \mathrm{Z}_{4}+\mathrm{D}
\end{array}
$$

$$
\begin{array}{cl}
-\mathrm{R}_{\mathrm{W}}{ }^{*} \mathrm{X}_{\mathrm{W}} & \\
\hdashline \pi^{*} & \alpha_{\mathrm{W}}+\gamma_{\mathrm{WW}} \ln \mathrm{R}_{\mathrm{W}}{ }^{*}+\gamma_{\mathrm{WS}} \ln \mathrm{R}_{\mathrm{S}}{ }^{*}+ \\
& \gamma_{\mathrm{WUR}} \ln \mathrm{R}_{\mathrm{UR}}+\gamma_{\mathrm{WT}} \ln \mathrm{R}_{\mathrm{T}}{ }^{*}+ \\
& \gamma_{\mathrm{W} 1} \ln \mathrm{Z}_{1}+\gamma_{\mathrm{W} 2} \ln \mathrm{Z}_{2}+\gamma_{\mathrm{W} 3} \ln \mathrm{Z}_{3}+ \\
& \gamma_{\mathrm{W} 4} \ln \mathrm{Z}_{4}+\mathrm{D}
\end{array}
$$

Elastisitas Permintaan Input diduga dengan persamaan sebagai berikut:

\section{Elastisitas Permintaan Input}

Elastisitas permintaan input terhadap harga sendiri (eii):

$$
e_{i i}=-S_{i}^{*}-1-\frac{\gamma_{i i}}{S_{i}^{*}}
$$

dimana: $S^{*}$ adalah dugaan $S_{i}$ dari tahun yang ditentukan.

a. Elastisitas permintaan silang input terhadap harga input lain ( $\left.\mathrm{e}_{\mathrm{ih}}\right)$ :

$$
e_{i h}=-S_{h}{ }^{*}-\frac{\gamma_{i i}}{S_{i}^{*}} ; \text { dimana } \mathrm{i} \neq \mathrm{h}
$$

b. Elastisitas permintaan input terhadap harga output $\left(\mathrm{e}_{\mathrm{iy}}\right)$ :

$$
\begin{aligned}
& e_{i y}=\sum_{i=1}^{n} S_{i}^{*}+1+\sum_{h=1}^{n} \frac{\gamma_{i h}}{S_{i}^{*}} \\
& \text { dimana } \mathrm{i}=1,2, \ldots, \mathrm{n} \quad \mathrm{h}=1,2, \ldots, \mathrm{n}
\end{aligned}
$$

\section{Elastisitas penawaran Hasil}

a. Elastisitas suplai (penawaran terhadap harga input variable ke -i adalah:

$$
e_{v i}=-S_{i}^{*}-\sum_{h=1}^{n} \gamma_{h i} /\left[1+\sum_{h=1}^{n} S_{h}^{*}\right]
$$

b. Elastisitas penawaran terhadap harga sendiri sebagai berikut:

$$
e_{v v}=\sum_{i=1}^{n} S_{i}^{*}-\sum_{i=1}^{n} \sum_{h=1}^{n} \gamma_{i h} /\left[1+\sum_{h=1}^{n} S_{h}^{*}\right]
$$

c. Elastisitas penawaran output terhadap input tetap $\mathrm{Z}_{\mathrm{k}}$ :

$$
\begin{aligned}
e_{v k}= & \sum_{i=1}^{n} \delta_{i k} \ln P i+\beta i k- \\
& \sum_{i=1}^{n} \delta_{i k} /\left[1+\sum_{h=1}^{n} S_{h}^{*}\right]
\end{aligned}
$$

Asumsi keuntungan maksimum yang harus dipenuhi adalah persyaratan-persyaratan simetri, homogen terhadap input dan output, kemonotonikan, dan kekonvekan. Model fungsi keuntungan translog diduga dengan metode SUR (Seemingly Unrelated Regression). Pengujian hipotesis dengan menggunakan uji $t$.

\section{HASIL DAN PEMBAHASAN}

Perkembangan Harga Output, Input dan Infrastruktur Jagung

Perkembangan Harga Output dan Input di Provinsi Jawa Timur. Perkembangan harga jagung di provinsi Jawa Timur seperti disajikan pada Tabel 1 dalam kurun waktu 1985-2009 mengalami peningkatan sebesar 10,62 persen per tahun. Harga jagung pipilan kering pada tahun 1985 sebesar Rp 129/kg, dan selanjutnya pada tahun 2009 menjadi Rp 2 200/kg. Menurut Kasryno, et.al., (2007) bahwa perubahan harga jagung lebih terdorong karena permintaan jagung terutama untuk kebutuhan bahan baku pakan dan industri. Bahkan harga jagung internasional peningkatannya akan terus terjadi seiring dengan meningkatnya permintaan untuk industri etanol sebagai bahan bakar nabati. 
Tabel 1. Rata-rata Harga Jagung dan Input Usahatani Jagung di Provinsi Jawa Timur, Tahun 1985-2009

\begin{tabular}{|c|c|c|c|c|c|}
\hline Tahun & $\begin{array}{l}\text { Jagung } \\
\text { (Rp/kg) }\end{array}$ & Benih (Rp/kg) & Urea (Rp/kg) & TSP (Rp/kg) & $\begin{array}{c}\text { Upah T.Kerja } \\
\text { (Rp/HOK) }\end{array}$ \\
\hline 1985 & 129 & 182 & 98 & 100 & 792 \\
\hline 1990 & 202 & 350 & 229 & 248 & 1.180 \\
\hline 1995 & 339 & 823 & 310 & 419 & 2.524 \\
\hline 2000 & 852 & 2.893 & 1.016 & 1.352 & 5.813 \\
\hline 2001 & 1.083 & 3.800 & 1.142 & 1.451 & 6.485 \\
\hline 2002 & 1.109 & 5.192 & 1.282 & 1.624 & 7.649 \\
\hline 2003 & 1.135 & 6.813 & 1.357 & 1.982 & 8.146 \\
\hline 2004 & 1.169 & 7.638 & 1.522 & 2.060 & 8.111 \\
\hline 2005 & 1.229 & 10.000 & 1.360 & 3.045 & 8.889 \\
\hline 2006 & 1.456 & 10.769 & 1.540 & 3.704 & 13.185 \\
\hline 2007 & 1.869 & 13.636 & 1.829 & 1.782 & 17.023 \\
\hline 2008 & 2.201 & 15.417 & 2.207 & 2.440 & 16.983 \\
\hline 2009 & 2.200 & 15.982 & 2.215 & 2.630 & 18.145 \\
\hline Rata-rata & 778 & 4.151 & 816 & 1.138 & 5.639 \\
\hline \multicolumn{6}{|c|}{ Perkemb (\%/thn) } \\
\hline $1985-2009$ & 10,62 & 14,77 & 10,97 & 11,32 & 11,92 \\
\hline 2000-2009 & 3,40 & 14,45 & 4,93 & 5,17 & 16,23 \\
\hline
\end{tabular}

Sumber: Struktur Ongkos Usahatani Jagung (BPS, 1985-2009; Pusdatin-kementan, 2005-2007; dan Dinas Pertanian Jawa Timur, 2001-2009).

Hal ini dipicu karena semakin meningkatnya harga minyak bumi. Semakin meningkatnya harga jagung diharapkan akan semakin meningkatnya pendapatan petani, dengan syarat jika kenaikan harga input tidak lebih tinggi dari kenaikan harga jagung serta tingkat produktivitas jagung stabil.

Menurut Hartoyo (1994) bahwa tinggi rendahnya produksi yang akan dicapai, selain ditentukan oleh teknologi yang digunakan juga ditentukan oleh tinggi rendahnya harga input dan harga output yang terjadi. Harga benih jagung dari tahun 1985-2009 cenderung meningkat sebesar 14,77 persen. Lonjakan harga benih jagung cukup tajam mulai tahun 2005 yaitu menjadi sebesar Rp10.000/kg, dan selanjutnya pada tahun 2009 menjadi Rp15.982/ kg. Tingginya harga benih jagung disebabkan oleh semakin mahalnya benih jagung hibrida yang rata-rata saat ini dapat mencapai $\mathrm{Rp} 25.000 / \mathrm{kg}$.

Sementara untuk harga pupuk urea dan TSP dalam kurun waktu 1985-2009 juga mengalami peningkatan sebesar 10,97 dan 11,32 persen per tahun. Peningkatan harga pupuk tersebut disebabkan oleh semakin menurunnya subsidi yang dialokasikan oleh pemerintah per jenis pupuknya. Menurut Nuryartono (2009) bahwa meskipun besar subsidi semakin meningkat, namun meningkatnya jumlah besaran subsidi pupuk juga diiringi oleh meningkatnya jenis pupuk yang disubsidi dan juga biaya produksi pupuk. Meskipun harga pupuk urea dan TSP semakin meningkat, namun jumlah penggunaan pupuk dalam periode tersebut juga relatif meningkat.

Untuk upah tenaga kerja, selama kurun waktu 1985-2009 mengalami peningkatan sebesar 11,92 persen pertahun. Upah tenaga kerja pada tahun 1985 sebesar Rp792/HK, kemudian upah tenaga kerja meningkat sejak tahun 2003, yaitu mencapai Rp8.146/HK. Selanjutnya pada tahun 2009, upah tenaga kerja meningkat tajam lebih dari dua kali lipat menjadi Rp18.145/HK.

Perkembangan Harga Output dan Input di provinsi Jawa Barat. Perkembangan harga jagung di provinsi Jawa Barat dalam kurun waktu 1985-2009 mengalami peningkatan sebesar 9,95 persen per tahun (Tabel 2). Harga jagung pipilan kering pada tahun 1985 sebesar $\mathrm{Rp} 161 / \mathrm{kg}$, dan selanjutnya pada tahun 2009 menjadi Rp2 100/kg. Seperti halnya di provinsi Jawa Timur, bahwa peningkatan harga jagung di Jawa Barat juga terdorong karena permintaan jagung terutama untuk kebutuhan bahan 
Tabel 2. Rata-rata Harga Jagung dan Input Benih Pada Usahatani Jagung di Provinsi Jawa Barat, Tahun 1985-2009

\begin{tabular}{cccccc}
\hline Tahun & $\begin{array}{c}\text { Jagung } \\
\mathbf{( R p / k g )}\end{array}$ & Benih (Rp/kg) & Urea (Rp/kg) & TSP (Rp/kg) & $\begin{array}{c}\text { Upah T.Kerja } \\
(\mathbf{R p} / \text { HOK) }\end{array}$ \\
\hline 1985 & 161 & 260 & 105 & 102 & 779 \\
1990 & 209 & 569 & 219 & 228 & 1.277 \\
1995 & 379 & 1.486 & 348 & 475 & 2.759 \\
2000 & 989 & 3.280 & 1.353 & 1.389 & 6.994 \\
2001 & 1.199 & 3.341 & 1.421 & 1.563 & 7.923 \\
2002 & 1.329 & 4.075 & 1.609 & 1.667 & 9.409 \\
2003 & 1.009 & 3.776 & 1.675 & 1.950 & 10.931 \\
2004 & 1.269 & 2.508 & 1.701 & 2.033 & 10.516 \\
2005 & 1.362 & 8.790 & 1.650 & 2.100 & 11.733 \\
2006 & 1.510 & 9.704 & 1.750 & 2.200 & 17.011 \\
2007 & 1.650 & 14.645 & 2.300 & 2.800 & 19.450 \\
2008 & 1.912 & 18.946 & 2.600 & 3.600 & 18.024 \\
2009 & 2.100 & 24.582 & 3.303 & 4.060 & 19.689 \\
Rata-rata & 788 & 4.475 & 1.008 & 1.224 & 6.553 \\
\hline Perkemb(\%/thn) & & & & & 12,10 \\
$1985-2009$ & 9,95 & 14,75 & 11,42 & 11,80 & 11,72 \\
\hline
\end{tabular}

Sumber: Struktur Ongkos Usahatani Jagung (BPS, 1985-2009; Pusdatin- Kementan, 2005-2007; dan Dinas Pertanian Jawa Barat, 2001-2009).

baku pakan dan industri.

Selanjutnya untuk harga benih jagung, selama kurun waktu 1985-2009 cenderung meningkat sebesar 14,75 persen. Lonjakan harga benih jagung cukup tajam mulai tahun 2005 yaitu menjadi $\mathrm{Rp} 8.790 / \mathrm{kg}$, dan pada tahun 2009 harganya menjadi tiga kali lipat yaitu Rp $24.582 / \mathrm{kg}$. Tingginya harga benih jagung disebabkan oleh semakin mahalnya benih jagung terutama benih jagung hibrida.

Sementara untuk harga pupuk urea dan TSP dalam kurun waktu 1985-2009 juga mengalami peningkatan sebesar 11,42 dan 11,80 persen per tahun. Meningkatnya harga pupuk urea dan TSP di Jawa Barat, juga diiringi oleh sedikit menurunya jumlah penggunaan pupuk dalam periode tersebut. Penggunaan pupuk di tingkat usahatani tentunya sesuai dengan kemampuan modal yang dimiliki petani.

Untuk upah tenaga kerja, selama periode 1985-2009 mengalami peningkatan sebesar 12,10 persen pertahun. Upah tenaga kerja pada tahun 1985 sebesar Rp779/HK, dan mulai tahun 2002 meningkat cukup tinggi mencapai Rp9.409/HK. Selanjutnya pada tahun 2009, upah tenaga kerja meningkat tajam lebih dari dua kali lipat menjadi Rp19.689/HK.

Pengeluaran Riset dan Pengembangan Jagung Pemerintah. Pengeluaran riset jagung dalam penelitian ini merupakan pengeluaran untuk kegiatan riset atau penelitian jagung yang dilakukan oleh instansi pemerintah khususnya pada Badan Penelitian dan Pengembangan Pertanian, yaitu pengeluaran riset dan pengembangan pada Balai Penelitian Serealia. Pengeluaran riset untuk jagung pada tahun 1985 mencapai 818,95 juta rupiah, kemudian meningkat menjadi 2,59 milyar rupiah pada tahun 1998 dan selanjutnya meningkat menjadi 11,77 milyar rupiah pada tahun 2009 (Statistik Badan Litbang Pertanian, 1985-2009). Rata-rata peningkatan pengeluaran riset jagung periode 1985-2009 mencapai 12,07 persen per tahun (Tabel 3).

Bila dilihat pangsa pengeluaran riset jagung terhadap anggaran total riset pada tahun 1985 mencapai 2,55 persen, dan bahkan pangsanya menurun menjadi 1,76 persen pada tahun 2009. Alokasi biaya riset jagung masih rendah. Di sisi lain bahwa, target peningkatan produksi jagung nasional terus meningkat seiring dengan meningkatnya kebutuhan jagung. Namun de- 
Tabel 3. Perkembangan Pengeluaran Riset Jagung Lingkup Pertanian di Indonesia, Tahun 19852009

\begin{tabular}{cccc}
\hline Tahun & $\begin{array}{c}\text { Pengeluaran Riset dan } \\
\text { Pengembangan Jagung } \\
\text { (Rp000) }\end{array}$ & $\begin{array}{c}\text { Anggaran Litbang } \\
\text { Pertanian (Rp000) }\end{array}$ & $\begin{array}{c}\text { Pangsa Pengeluaran Riset } \\
\text { Jagung Terhadap } \\
\text { Anggaran Litbang (\%) }\end{array}$ \\
\hline 1985 & 818.950 & 32.082 .476 & 2,55 \\
1990 & 755.317 & 25.731 .175 & 2,94 \\
1995 & 2.285 .036 & 104.607 .000 & 2,18 \\
2000 & 2.992 .252 & 119.790 .308 & 2,50 \\
2005 & 8.601 .731 & 377.580 .338 & 2,28 \\
2009 & 11.766 .465 & 737.668 .646 & 1,60 \\
Perkemb $\% /$ thn) & 12,07 & 13,17 & $-1,29$ \\
\hline
\end{tabular}

Sumber: Statistik Badan Litbang Pertanian, 1985-2009

mikian, meskipun alokasi anggaran riset masih terbatas, riset jagung terus ditingkatkan yang juga mendapatkan dukungan dari pihak swasta dan lembaga riset internasional.

Infrastruktur Jalan. Jalan merupakan salah satu prasarana penting dalam transportasi darat. Hal ini karena fungsi strategis yang dimilikinya, yaitu sebagai penghubung antarsatu daerah dengan daerah lain. Jalan sebagai sentra penghubung antara sentra-sentra produksi dengan daerah pemasaran, sangat dirasakan manfaatnya dalam rangka meningkatkan perekonomian suatu wilayah (BPS, 2009). Data panjang jalan yang ada pada setiap propinsi merupakan penjumlahan panjang jalan menurut tingkat kewenangan pembinaannya, dan juga berdasarkan kualitas jalan (beraspal, kerikil, tanah dan lainnya).

Menurut BPS (2009), bahwa saat ini jalan kabupaten/kota masih merupakan bagian terbesar yaitu 389,75 ribu kilometer atau 82 persen dari total panjang jalan di Indonesia, sedangkan jalan provinsi dan negara masing-masing sebesar 48,02 ribu kilometer dan 38,57 kilometer atau 10,08 persen dan 8,10 persen. Jenis permukaan jalan terdiri dari: aspal, kerikil, tanah dan lainnya. Jalan beraspal proporsinya paling besar yaitu 56,94 persen, sedangkan jalan dengan permukaan kerikil sebesar 21,60 persen, permukaan tanah sebesar 17,59 persen dan lainnya sebesar 3,87 persen (Tabel 4).

Di provinsi Jawa Timur, total panjang jalan pada periode 1985-2009 meningkat dari 18405 kilometer (1985) menjadi 38.565 kilometer (2009) atau peningkatannya sebesar 2,11 persen per tahun. Sementara di Jawa Barat, pada periode yang sama peningkatannya dari 12.500 kilometer (1985) menjadi 20.761 kilometer (2009)

Tabel 4. Perkembangan Total Panjang Jalan di Provinsi Jawa Timur dan Jawa Barat, Tahun 19852009

(Kilometer)

\begin{tabular}{cccc}
\hline Tahun & Jawa Timur & Jawa Barat & Rata-rata \\
\hline 1985 & 18.405 & 12.500 & 15.453 \\
1990 & 26.948 & 17.940 & 22.444 \\
1995 & 22.120 & 22.036 & 22.078 \\
2000 & 27.777 & 23.993 & 25.885 \\
2005 & 36.803 & 23.118 & 29.960 \\
2006 & 36.337 & 21.290 & 28.813 \\
2007 & 37.027 & 21.744 & 29.386 \\
2008 & 37.814 & 37.732 & 37.773 \\
2009 & 38.565 & 22.758 & 30.661 \\
Rata-rata & 28.385 & 20.761 & 24.573 \\
Perkemb $\%$ thn $)$ & 2,11 & 2,39 & 2,23 \\
\hline
\end{tabular}

Sumber: BPS Jatim (1985-2010), BPS Jabar (1985-2010), Statistik Indonesia (1985-2010), Statistik Transportasi/Perhubungan (1989-2009). 
atau peningkatannya sebesar 2,39 persen per tahun. Secara rata-rata, panjang jalan di kedua provinsi tersebut meningkat sebesar 2,23 persen per tahun, yaitu dari 15.453 kilometer pada tahun 1985 menjadi 30.661 kilometer pada tahun 2009.

Pengelolaan infrastruktur di pedesaan merupakan salah satu langkah kebijakan penting bagi percepatan pembangunan di pedesaaan (Sinar Tani, Mei 2011). Jenis infrastruktur dipedesaan yang dipentingkan antara lain adalah jalan yang masuk ke pedesaaan. Semakin terbuka dan aksesnya infrastruktur jalan ke pedesaan akan mempermudah arus barang dari dan ke pedesaan itu sendiri. Infrastruktur jalan yang baik akan menjadi lebih murah biaya transportasi, sehingga input-input pertanian yang dibutuhkan oleh para petani dipedesaan akan semakin mudah diperoleh dan harganya pun murah. Pada sisi lain, proses penjualan hasil pun jika dijual ke perkotaan akan semakin mudah.

\section{Dugaan Elastisitas Penawaran Output}

Di provinsi Jawa Timur, nilai elastisitas penawaran output (jagung) terhadap harga sendiri bernilai positif dan elastis yaitu sebesar 1.6645 (Tabel 5). Nilai elastisitas pen awaran harga yang elastis tersebut mengindikasikan bahwa respon petani jagung terhadap perubahan harga sangat besar. Oleh karena itu, perubahan harga jagung akan sangat menentukan kebijakan pengembangan jagung.

Nilai elastisitas penawaran terhadap harga input: benih, pupuk urea, pupuk TSP dan tenaga kerja seluruhnya bernilai inelastis dan bertanda negatif, yang masing-masing sebesar 0,$3328 ;-0,2489 ;-0,2538 ;-0,8290$. Benih dan tenaga kerja berpengaruh nyata terhadap output yang ditawarkan. Hal ini disebabkan karena harga benih dan upah tenaga kerja cenderung mahal. Harga benih dan upah tenaga kerja tahun 2009 di Jawa Timur masing-masing sebesar Rp15.982/kg dan Rp18.145/HK.

Sementara itu, di provinsi Jawa Barat, nilai elastisitas penawaran output terhadap harga sendiri juga elastis dengan nilai 1,7372. Nilai elastisitas penawaran terhadap harga input (benih, urea, TSP dan tenaga kerja) bernilai inelastis dan bertanda negatif yaitu masing-masing $-0,2886 ;-0,2656 ;-0,2325$; dan $-0,997$. Harga input benih dan tenaga kerja berpengaruh nyata terhadap penawaran jagung (Tabel 6). Harga

Tabel 5. Dugaan Elastisitas Penawaran Output dan Permintaan Input Jagung di Provinsi Jawa Timur, tahun 2009

\begin{tabular}{lccccc}
\hline \multicolumn{1}{c}{ Peubah } & Jagung & Benih & Pupuk Urea & Pupuk TSP & Tenaga Kerja \\
\hline Harga Jagung & $1,6645^{* *}$ & $1,5072^{* * *}$ & 1,5536 & 1,6714 & $1,4530^{* *}$ \\
& $(2,3211)$ & $(1,4851)$ & $(0,4101)$ & $(0,1799)$ & $(1,7788)$ \\
Harga Benih & $-0,3328^{* * *}$ & $-0,5499^{*}$ & $-0,2892^{* *}$ & $-0,2527$ & $-0,1220^{*}$ \\
& $(-1,4851)$ & $(-1,6797)$ & $(-1,7931)$ & $(-0,5022)$ & $(-2,1024)$ \\
Harga Urea & $-0,2489$ & $-0,2807^{* *}$ & $-0,5034$ & $-0,4334^{* * *}$ & $-0,1335$ \\
& $(-0,4101)$ & $(-1,7931)$ & $(-1,1206)$ & $(-1,5139)$ & $(-0,9403)$ \\
Harga TSP & $-0,2538$ & $-0,0393$ & $-0,1298^{* * *}$ & $-0,2751$ & $-0,0522^{* *}$ \\
& $(-0,1799)$ & $(-0,5022)$ & $(-1,5139)$ & $(-0,7696)$ & $(-1,8676)$ \\
Upah Tenaga Kerja & $-0,8290^{* *}$ & $-0,6373^{* *}$ & $-0,6312$ & $-0,7102^{* * *}$ & $-1,1453^{* *}$ \\
& $(-1,7788)$ & $(-2,1024)$ & $(-0,9403)$ & $(-1,4676)$ & $(-1,8074)$ \\
Biaya Lain & $-1,1980^{* *}$ & $-1,2922^{* *}$ & $-1,3474^{* *}$ & $-1,4471^{* *}$ & $-1,0523$ \\
& $(-2,1968)$ & $(-2,32)$ & $(-2,3213)$ & $(-1,8594)$ & $(-1,0497)$ \\
Luas Panen & $1,6378^{* *}$ & $1,6997^{* *}$ & $1,5862^{* *}$ & $1,0220^{*}$ & 1,3523 \\
& $(2,1870)$ & $(2,0880)$ & $(2,2251)$ & $(5,2188)$ & $(1,2729)$ \\
Pengel, Riset Jagung & $0,9880^{* * *}$ & $0,9057^{* * *}$ & $0,9160^{* * *}$ & $0,8642^{* * *}$ & 0,7421 \\
Infrastruktur jalan & $(1,3515)$ & $(1,3783)$ & $(1,3659)$ & $(1,4951)$ & $(1,0636)$ \\
& $1,3025^{* * *}$ & $1,4795^{* * *}$ & $1,5532^{* * *}$ & $1,6512^{* * *}$ & 1,1686 \\
& $(1,5448)$ & $(1,3601)$ & $(1,9214)$ & $(1,4695)$ & $(0,0437)$ \\
\hline
\end{tabular}

Keterangan: Angka dalam kurung adalah $\mathrm{t}$ hitung ; *) signifikan pada taraf $\alpha=1$ persen,

${ }^{* *}$ ) signifikan pada taraf $\alpha=5$ persen, ${ }^{* * *}$ ) signifikan pada taraf $\alpha=10$ persen 
benih dan upah tenaga kerja tahun 2009 di Jawa Barat cenderung mahal yaitu masing-masing sebesar Rp24.582/kg dan Rp19.689/HK. Semakin meningkatnya upah tenaga kerja pada usahatani jagung, disebabkan oleh semakin sulitnya memperoleh tenaga kerja usahatani. Hal ini karena banyaknya tenaga kerja terutama generasi muda di pedesaan yang bekerja di sektor non pertanian.

Elastisitas Permintaan Input. Di Provinsi Jawa Timur, permintaan input benih dipengaruhi secara nyata oleh perubahan harga sendiri. Nilai elastisitas benih terhadap harga sendiri sebesar $-0,5499$. Faktor yang menyebabkannya adalah karena harga benih yang cenderung meningkat sebesar 14,77 persen per tahun dalam periode 1985-2009. Sementara elastisitas permintaan benih dipengaruhi oleh perubahan harga urea dan tenaga kerja. Selanjutnya diketahui bahwa permintaan pupuk urea dan TSP tidak dipengaruhi oleh perubahan harga sendiri. Nilai elastisitas permintaan input urea dan TSP terhadap harga sendiri adalah inelastis yaitu masing-masing sebesar $-0,6628$ dan $-0,4832$ (Tabel 5). Hal ini mencerminkan bahwa permintaan pupuk urea dan TSP tidak responsif terhadap perubahan harga sendiri. Sementara untuk permintaan tenaga kerja dipengaruhi secara nyata oleh upah tenaga kerja dengan nilai elastisitasnya sebesar $-1,1453$ (elastis).

Sementara itu, di provinsi Jawa Barat permintaan input benih inelastis terhadap perubahan harga sendiri, yaitu sebesar -0,3810. Hal ini berarti jika harga benih naik sebesar 1 persen maka permintaan benih akan turun sebesar 0,3810 persen. Elastisitas permintaan benih dipengaruhi oleh perubahan harga pupuk urea dan upah tenaga kerja. Selanjutnya elastisitas pupuk urea dipengaruhi secara nyata oleh perubahan harga sendiri. Nilai elastisitas permintaan pupuk urea terhadap harga sendiri sebesar $-0,4473$. Permintaan pupuk urea ini juga dipengaruhi oleh perubahan harga benih, harga pupuk TSP dan upah tenaga kerja. Pupuk urea dan TSP bersifat komplementer. Lain halnya dengan permintaan pupuk TSP tidak dipengaruhi secara nyata oleh perubahan harga sendiri. Nilai elastisitas permintaan pupuk TSP terhadap harga sendiri adalah inelastis yaitu sebesar
-0,6392. Permintaan pupuk TSP ini justru dipengaruhi oleh perubahan upah tenaga kerja dan harga pupuk urea. Permintaan tenaga kerja juga dipengaruhi secara nyata oleh perubahan upah tenaga kerja. Elastisitas yang diperoleh adalah elastis yaitu sebesar -1,2894. Permintaan tenaga kerja juga dipengaruhi oleh perubahan harga benih, harga pupuk urea dan pupuk TSP (Tabel 6).

Elastisitas Penawaran Output dan Permintaan input Terhadap Pengeluaran Riset Jagung dan Prasarana (panjang) Jalan. Di Provinsi Jawa Timur dan Jawa Barat, perubahan pengeluaran riset dan infrastruktur jalan memiliki pengaruh nyata terhadap penawaran jagung. Elastisitas penawaran jagung terhadap kedua infrastruktur tersebut yaitu sebesar 0,9880 dan 1,3025 di Jawa Timur, dan sebesar 0,9884 dan 1,3022 di Jawa Barat (Tabel 5 dan Tabel 6).

Anggaran riset jagung khusus pada lembaga pemerintah saat ini masih terbatas. Pada tahun 2009 anggaran riset jagung di lingkup penelitian dan pengembangan pertanian hanya sekitar 1,60 dari total anggaran riset keseluruhan pertanian. Namun demikian, dengan keterbatasan anggaran masih dapat meningkatkan penawaran jagung di kedua provinsi. Menurut hasil penelitian Nagy and Alam (2000) bahwa terdapatnya riset atas varietas unggul seperti padi di Bangladesh telah diadopsi petani dan memberikan dampak peningkatan hasil dibandingkan dengan varietas yang lama.

Untuk infrastruktur jalan, dengan melihat besarnya elastisitas bahwa peningkatan kuantitas dan kualitas sarana transportasi memiliki potensi besar terhadap peningkatan produksi pertanian. Menurut Delis (2011) bahwa pembangunan infrastruktur seperti jalan memiliki dampak besar terhadap aktivitas ekonomi di wilayah sentra produksi. Selanjutnya hasil penelitian Wahab (2009) mengungkapkan bahwa peningkatan infrastruktur jalan pada suatu wilayah di Sulawesi Selatan berperan penting dalam kegiatan ekonomi wilayah yaitu berupa peningkatan distribusi pangan dan perdagangan. Hasil penelitian lainnya yaitu Dhakal (2009) mengungkapkan bahwa ketika infrastruktur jalan buruk di Davao Filipina maka partisipasi petani terhadap akses pasar terbatas. 
Tabel 6. Dugaan Elastisitas Penawaran Output dan Permintaan Input Jagung di Provinsi Jawa Barat, tahun 2009

\begin{tabular}{lccccc}
\hline \multicolumn{1}{c}{ Peubah } & Jagung & Benih & Pupuk Urea & Pupuk TSP & Tenaga Kerja \\
\hline Harga Jagung & $1,7372^{*}$ & $1,4964^{* *}$ & 1,6471 & 1,5331 & $1,5562^{* * *}$ \\
& $(3,7154)$ & $(1,7765)$ & $(0,6564)$ & $(0,2879)$ & $(1,4467)$ \\
Harga Benih & $-0,2886^{* *}$ & $-0,3810^{* *}$ & $-0,3431^{*}$ & $-0,1504$ & $-0,1101^{*}$ \\
& $(-1,7765)$ & $(-1,7277)$ & $(-2,8703)$ & $(-0,8040)$ & $(-3,3654)$ \\
Harga Urea & $-0,2656$ & $-0,2577^{*}$ & $-0,4473^{* *}$ & $-0,0287^{* * *}$ & $-0,0983^{* * *}$ \\
& $(-0,6564)$ & $(-2,8703)$ & $(-1,7938)$ & $(-1,4629)$ & $(-1,5052)$ \\
Harga TSP & $-0,2325$ & $-0,0589$ & $-0,1434^{* * *}$ & $-0,6392$ & $-0,0584^{*}$ \\
& $(-0,2879)$ & $(-0,8040)$ & $(-1,4629)$ & $(-1,2320)$ & $(-2,9895)$ \\
Upah Tenaga Kerja & $-0,9770^{* * *}$ & $-0,7988^{*}$ & $-0,7133^{*}$ & $-0,7148^{*}$ & $-1,2894^{*}$ \\
& $(-1,4467)$ & $(-3,3654)$ & $(-1,5052)$ & $(-2,9895)$ & $(-2,8931)$ \\
Biaya Lain & $-1,2525^{* *}$ & $-1,2781^{*}$ & $-1,5609^{*}$ & $-1,3781^{*}$ & $-0,9245^{* * *}$ \\
& $(-2,0701)$ & $(-3,7209)$ & $(-3,7157)$ & $(-2,9763)$ & $(-1,6803)$ \\
Luas Panen & $1,4032^{* *}$ & $1,5938^{* *}$ & $1,5586^{* *}$ & $1,6557^{*}$ & 1,4120 \\
& $(1,9117)$ & $(2,2857)$ & $(2,3834)$ & $(2,3538)$ & $(1,2082)$ \\
Pengel. Riset Jagung & $0,9884^{*}$ & $0,9003^{* * *}$ & $0,9151^{* * *}$ & 0,8811 & 0,6687 \\
& $(2,1314)$ & $(1,4585)$ & $(1,3535)$ & $(1,4682)$ & $(1,0348)$ \\
Infrastruktur jalan & $1,3022^{* * *}$ & $1,4733^{* * *}$ & $1,5731^{* * *}$ & $1,5552^{* * *}$ & 1,1401 \\
& $(1,3522)$ & $(1,3501)$ & $(1,4302)$ & $(1,4652)$ & $(1,1864)$ \\
\hline
\end{tabular}

Keterangan: Angka dalam kurung adalah $\mathrm{t}$ hitung ; *) signifikan pada taraf $\mathrm{a}=1$ persen;

**) signifikan pada taraf $\alpha=5$ persen, ${ }^{* * *}$ ) signifikan pada taraf $\alpha=10$ persen

Di Provinsi Jawa Timur dan Jawa Barat, pengeluaran riset jagung dan infrastruktur jalan tidak berpengaruh nyata terhadap permintaan input. Namun demikian, dengan melihat besarnya nilai elastisitas terutama infrastruktur jalan di kedua provinsi yang rata-rata positif di atas satu menunjukkan bahwa peluang peningkatan permintaan input cukup besar jika terjadi peningkatan infrastruktur jalan. Semakin meningkatnya infrastruktur jalan, biaya transportasi akan semakin rendah, sehingga harga input usahatani juga rendah.

\section{SIMPULAN}

Elastisitas penawaran output (jagung) baik di Provinsi Jawa Timur maupun di Jawa Barat terhadap perubahan harga sendiri adalah elastis, sedangkan terhadap perubahan harga input: benih, urea, TSP dan tenaga kerja adalah inelastis. Elastisitas permintaan input: benih, pupuk urea, dan pupuk TSP bersifat inelastis terhadap perubahan harga sendiri.

Pengeluaran riset jagung berpengaruh positif terhadap penawaran jagung baik di Pro- vinsi Jawa Timur maupun di Jawa Barat, dengan nilai elastisitas yang inelastis. Sementara infrastruktur jalan berpengaruh positif terhadap penawaran jagung di kedua provinsi dengan nilai elastisitas yang elastis. Oleh karena itu, kebijakan peningkatan riset dan pengembangan jagung serta peningkatan infrastruktur jalan akan dapat mendorong peningkatan penawaran jagung baik di Jawa Barat maupun Jawa Timur.

Secara umum selain upaya yang perlu dilakukan di atas, maka untuk meningkatkan penawaran jagung adalah dengan meningkatkan harga jagung di kedua provinsi penelitian. Meskipun harga input usahatani meningkat (pupuk dan benih) seperti terjadi saat ini, namun bila harga output meningkat, maka produksi jagung masih dapat meningkat. Oleh karena itu, stabilitas dan peningkatan harga jagung memiliki peran penting dalam peningkatan produksi. Upaya stabilitas dan peningkatan harga jagung dapat dilakukan oleh pemerintah daerah provinsi dengan membeli jagung terutama disaat panen. Untuk lebih mendorong peningkatan produksi masih perlu mendapat subsidi bagi petani dalam bentuk subsidi harga output dan 
bunga modal usaha mengingat kondisi petani jagung nasional terutama di Pulau Jawa merupakan petani kecil berlahan sempit dan memiliki keterbatasan modal.

\section{DAFTAR PUSTAKA}

Adeleke, H.M. Mattanmi and L.T. Ogunniyi. 2008. Application of the Normalized Profit Function in the Estimation of the Profit Efficiency Among Smallholder Farmers in Atiba Local Government of Oyo State. Journal of Economic Theory 2 (3); 71-76.

Badan Litbang Pertanian. 1985-2009. Statistik Penelitian. Jakarta: Badan Penelitian dan Pengembangan Pertanian.

Bisnis Indonesia. 2010. Penggunaan Benih Jagung Hibrida Meningkat. Bisnis Indonesia 17 September 2010, Jakarta.

BPS. 1985-1999. Struktur Ongkos Usahatani Padi dan Palawija di Indonesia. Jakarta: Badan Pusat Statistik.

BPS. 2003-2004. Hasil Survei Pertanian. Jakarta: Badan Pusat Statistik.

BPS. 2010. Data Produksi Pertanian. www. bps. go.id.

BPS. 2010. Jawa Timur Dalam Angka 2009. Surabaya: Badan Pusat Statistik

BPS. 2010. Jawa Barat dalam Angka 2009. Bandung: Badan Pusat Statistik.

Dhakal, N. 2009. Impact of Road Accessibility on Agricultural Production: Evidence From Mati, Davao Oriental Philippines. U.P. School or Urban and Regional Planning. Abstract Theses and Dissertations.

Debertin, D.L. 1986. Agricultural Production Economics. Macmilan Publishing Company 866 Third Avenue New York, New York 10022.366p.

Delis, A. 2011. Dampak Alokasi Dana Pembangunan Infrastruktur terhadap Kinerja Ekonomi Sektoral dan Regional Di Indonesia: Suatu Pendekatan Model Ekonomi Keseimbangan Umum.Abstrak Laporan
Penelitian Universitas Indonesia. http:// www.lontar.ui.ac.id.

Dinas Pertanian Tanaman Pangan Jawa Barat 2001-2008. Data Analisis Usahatani Jagung. Bandung: Dinas Pertanian Tanaman Pangan Jawa Barat.

Dinas Pertanian Tanaman Pangan Jawa Timur 2003-2009. Data Analisis Usahatani Jagung di Jawa Timur. Surabaya: Dinas Pertanian Tanaman Pangan Jawa Timur.

Direktorat Jenderal Tanaman Pangan, Departemen Pertanian. 2008. Bahan Laporan Bulanan Januari 2008 (Unpublished). Jakarta: Direktorat Jenderal Tanaman Pangan.

Direktorat Jenderal Tanaman Pangan, Departemen Pertanian. 2010. Road Map Swasembada Jagung 2010-2014. Jakarta: Direktorat Jenderal Tanaman Pangan.

Ekonomi dan Bisnis 2009. Indonesia Sudah Swasembada Jagung. Jakarta: Antara News.

Fan, S. 1991. Effect of Technological Change and Institutional Reform on Production Growth. American Journal of Agricultural Economics 73; 266-275.

FAO. 2009. Data Luas Panen, Produksi, Ekspor dan Impor Jagung. www.fao.org

Fulginiti, L.E and R.K. Perrin. 1990. Argaentine Agricultural Policy in Multiple-Input Multiple-Output Framework. American Journal of Agricultural Economics 72(2); 279288.

Hartoyo, S. 1994. Pengaruh Infrastruktur terhadap Penawaran Tanaman Pangan di Jawa. Pendekatan Multi-Input Multi-Output. Disertasi Program Pascasarjana IPB, Bogor.

Kasryno, F, E. Pasandaran, Suyamto dan M.O. Adnyana. 2007. Gambaran Umum Ekonomi Jagung Indonesia. Buku Jagung: Teknik Produksi dan Pengembangan. (Eds: Sumarno, Suyamto, A. Widjono, Hermanto, H. Kasim). Puslitbang Tanaman Pangan; 474-497.

Khatri, Y and C. Thirtle. 1996. Supply and Demand Function for UK Agricultural: 
Biases of Technical Change and the Return to Public Research and Development. Journal of Agricultural Economic, 47(3); 338-354.

Lau, L. J dan P.A, Yotopoulos. 1972. Profit, Supply, and Factor Demand Function. American Journal of Agricultural Economic. Vol.54, No.1; 11-18.

Lipsey, G, P.O. Steiner and D.D. Purvis. 1984. Economics. Seven edition. New York: Harper \& Row Publishers.

Mubyarto. 1989. Pengantar Ekonomi Pertanian. Edisi III. Jakarta: LP3ES.

Morlok, Edward K. 1988. Pengantar Teknik dan Perencanaan. Jakarta: Erlangga.

Nagy, J.G and M. F Alam. 2000. The Impact of Agricultural Research in Bangladesh: Productivity, Economic Returns and Varietal Replacement Issues. Paper Internastional Conference on Impact of Agricultural Research and Development, Feb 4-7, San Jose, Costarica.

Nuryartono, N. 2009. Subsidi Pupuk dan Permasalahannya. Makalah dalam bentuk PPt. International Center For Applied Finance and Economics (InterCAFE). IPB, Bogor.
Pindyck, R. S and D. L. Rubinfeld. 2005. Microeconomics. Sixth Edition. New Jersey: Perason Education, Inc. Upper Sadle River.

Pusat Data dan Informasi Pertanian 2002-2005. Data Hasil Survey Komoditas Jagung. Jakarta: Kementerian Pertanian.

Sidhu, S.S and C.A. Baanante. 1981. Estimating Farm-Level Input Demand and Wheat Supply in the Punjab Using a Translog Profit Function. American Journal of Agricultural Economics. Vol.63, No.2; 237-246.

Sinar Tani. 2011. Pengelolaaan Infrastruktur Pedesaaan. Edisi 4, Mei 2011, Jakarta.

Wahab, A. 2009. Dampak Peningkatan Kualitas Jalan Lingkar Barat Enrekang Terhadap Pengembangan Kawasan Pertanian. Tesis Magister Teknik, Program Pascasarjana Universitas Diponegoro, Semarang.

Zubachtirodin, M. S. Pabbage dan Subandi. 2007. Wilayah Produksi dan Potensi Pengembangan Jagung. Buku Jagung: Teknik Produksi dan Pengembangan. (Eds: Sumarno, Suyamto, A. Widjono, Hermanto, H. Kasim). Puslitbang Tanaman Pangan, Badan Litbang Pertanian; 464-473. 